Maija Sirola-Belliard

\title{
Suomen komitatiivisija - kiteytynyt vai produktiivinen?
}

\section{Johdanto ${ }^{1}$}

Komitatiivi on muoto, joka prototyyppisesti ilmaisee inhimillisten olentojen epäsymmetristä yhdessäoloa, ja maailman kielissä komitatiivi on tyypillisesti sijapääte, adpositio tai osa seriaaliverbirakennetta. Vaikka komitatiivin perusmerkitys, yhdessäolo, on kielen ytimen kannalta toissijainen, eikä sen morfologinen koodaus ole siten kielen systeemin kannalta keskeistä, useimmissa maailman kielissä on kieliopillinen keino yhdessäolon ilmaisuun. (Stolz ym. 2006; 2009.) Suomessa yhdessäolon ilmaisun muotoja ovat -inekomitatiivisija (kuten esimerkissä 1) sekä useat postpositiot, joista yleisin on kanssa (kuten esimerkissä 2).

(1) Tyttö istuskeli ystävineen jonkin aikaa stadionin viereisillä kallioilla ja lähti sitten yksin kävelemään kalliota ylöspäin. (HS 5701847) ${ }^{2}$

(2) Lauantaiaamuna Mimmu ja Tiia istuvat festivaalikahvilan pöydän ääressä ystäviensä kanssa. (HS 2718513)

Sijasysteemissä komitatiivi kuuluu spesifejä semanttisia suhteita ilmaiseviin konkreettisiin sijoihin. Se sisältyy tyypillisesti suuriin tai keskisuuriin sijasysteemeihin, joihin kuuluu syntaktisia ydinsuhteita ilmaisevien abstraktien sijojen lisäksi konkreettisia sijoja. Vaikka komitatiivisija onkin maailman kielissä suhteellisen harvinainen, se on yksi yleisimmistä ei-spatiaalisista konkreettisista sijoista maailman kielten sijasysteemeissä (Blake 2001, 158-159; Haspelmath 2009, 514).

1 Artikkeli on laajennettu ja syvennetty versio 38. Kielitieteen päivillä ja Språkets funktion 10 -symposiumissa pitämistäni esitelmistä sekä Nykysuomen seuran Kielikuvia-lehdessä (Sirola-Belliard 2013) julkaistusta populaaristetusta kirjoituksestani.

2 Kaikki artikkelin esimerkit ovat HS200o-korpuksesta (Pajunen 2003). Esimerkkien -ine- ja kanssa-ilmaukset on lihavoitu ja suhteen toista osapuolta kielentävä sana alleviivattu. HS-numerokoodi osoittaa ensimmäisen lihavoidun sanan positiota korpuksessa. Kiitän Sanoma Osakeyhtiötä korpuksen käyttömahdollisuudesta. 
Perusmerkityksensä lisäksi komitatiivi voi typologisesti ilmaista laajastikin erilaisia yhteisesiintymis- ja yhteenkuuluvuussuhteita. Tämä koskee myös suomen komitatiivisijaa, joka voi kirjoitetussa kielessä ilmaista prototyyppimerkityksensä lisäksi muun muassa omistussuhdetta, erilaisia osa-kokonaisuus-suhteita ja yhteen liittymistä sekä koko lauseen kontekstissa esimerkiksi välinettä, 'mukaan lukien' -merkitystä sekä syyn tai perustelun merkitystä. Monissa -ine-sijan merkityksissä ja samalla suuressa osassa -ine-sijan käytöstä on kyse elottomien olioiden välisestä suhteesta. Tämä onkin yksi -ine-sijaa ja kanssa-postpositiota erottavista seikoista: jälkimmäinen kun keskittyy pääasiassa ilmaisemaan komitatiiville tyypillisesti korkeaelollisten, siis inhimillisten olioiden suhteita. (Sirola-Belliard 2016.)

Monipuolisesta merkityskentästään huolimatta -ine-sija on suomen sijoista vähäkäyttöisin. Se kattaa promillen kirjoitetussa yleiskielessä käytetystä sijataivutuksesta, puhekielestä puoli promillea (yleiskielisissä teksteissä Hakulinen ym. 2004, 1179; murreaineistoissa Ikola 1999; ks. myös Pajunen 2010, 492-493). Näin on ilmeisesti ollut aina, ja tämä näkyy kirjallisissa lähteissä Agricolan kielestä alkaen (Häkkinen 1994, 208). Jos komitatiivia verrataan nyky-yleiskielessä suomen yleisimpiin paikallissijoihin (ks. Hakulinen ym. 2004, 1179) inessiiviin, elatiiviin ja illatiiviin, käytetään jälkimmäisiä kirjoitetussa kielessä jopa satakertaisesti komitatiivisijaan verrattuna. ${ }^{3}$ Osaltaan tähän vaikuttaa ero sijafunktioiden keskeisyydessä: ihmisten tai asioiden yhteisesiintymisen ilmaisu ei ole kielessä yhtä keskeistä kuin niiden sijainnin ilmaiseminen. Tämä ei kuitenkaan voi olla koko selitys, sillä -ine-sija on myös vähäkäyttöisempi kuin samaa perusmerkitystä ilmaiseva kanssapostpositio. Tähän vaikuttaa ainakin kaksi seikkaa (ks. tarkemmin Sirola-Belliard 2011, 2016).

Ensinnäkin kanssa-postpositiolle yleinen vastavuoroisen suhteen ilmaisu on -inesijalle mahdotonta, sillä se ei voi ilmaista itsenäisten tasaveroisten osapuolten suhdetta. -ine-sijalla kielennetty osapuoli osallistuu ilmaistuun asiantilaan välttämättä samassa roolissa kuin pääasiallinen toimija. Tätä havainnollistaa esimerkki 3, jossa Tuomioja ja kollegat ovat neuvotteluissa samalla puolella, ja vastakkaisen osapuolen ilmaisemiseen tarvitaan kanssa-postpositiota.

(3) Tuomioja ei kollegoineen aio käydä sissien kanssa suoria neuvotteluja Filippiinien hallituksen ohi. (HS 986799)

Toiseksi -ine-sija ei ole luonteva erisnimistä kuin harvoissa yhteyksissä ja lähinnä muussa kuin prototyyppimerkityksessä (kuten osista koostumisen merkityksessä, esimerkiksi Rolling Stones Mick Jaggereineen, HS 10945780, tai identifioivassa merkityksessä, esimerkiksi tuttujen amerikkalaissarjojen uusinnat Simpsoneineen, Ally McBealeineen [ja]

3 HS200o-korpuksessa on komitatiivisijaisia sanoja 0,12 \% kaikista korpuksen taivutetuista nomineista ( o,06 \% kaikista nomineista ja 0,02 \% kaikista korpuksen sanoista). Inessiivisijaisia sanoja on kaikista korpuksen taivutetuista nomineista $15,7 \%$, nomineista $6,5 \%$ ja sanoista $2,4 \%$; elatiivisijaisia sanoja on kaikista taivutetuista nomineista $10,8 \%$, nomineista $4,5 \%$ ja sanoista $1,7 \%$; illatiivisijaisia sanoja on kaikista taivutetuista nomineista $12,8 \%$, nomineista $5,3 \%$ ja sanoista $1,9 \%$. 
Teho-osastoineen, HS 1069002). Sen sijaan kanssa-postposition käytössä erisnimet ovat yhdessäolon ilmaisuissa hyvin yleisiä.

Todennäköisesti juuri -ine-sijan käytön pieni frekvenssi on johtanut arvioihin, että komitatiivin käyttö olisi rajoittunutta. Sitä on kuvattu kiteytyneeksi, vakiintuneeksi ja fraasiutuneeksi (esimerkiksi Vilkuna 2000, 81; Eskola-Tommola 2000, 97; myös ei-kielitieteellisessä keskustelussa, esim. Wikipedia, s.v. komitatiivi), ja komitatiivia sijana on pidetty epäproduktiivisena (Grünthal 2000, 48-49; 2003, 27). Oletusten perusteeksi ei kuitenkaan ole esitetty käyttöön perustuvaa aineistoa, vaan ne tuntuvat perustuvan enemmänkin intuitioon. Kutsun kirjallisuudessa esitetyn mukaista käyttöä yhteisesti kiteytyneeksi käytöksi, joka kattaa sekä fraasimaiset ilmaukset että komitatiivin ydinmerkitykseen lukeutuvan tavanomaisen käytön. Tässä artikkelissa tarkastelen -ine-komitatiivin käyttöä laajan tekstikorpuksen avulla ja tutkin, millaisina kiteytyneisyyden ja epäproduktiivisuuden oletukset näyttäytyvät sijan todellisen käytön valossa.

Aineistona käytän HS200o-korpusta (Pajunen 2003), joka on noin 31 miljoonan sanan sähköinen korpus Helsingin Sanomien vuosikerroista 2000 ja 2001. Se kattaa kaikki lehdissä ilmestyneet toimitetut tekstit (artikkelit, mainokset, tv- ja radio-ohjelmat, reseptit, mielipidekirjoitukset jne.) ja sisältää siten monipuolisesti erityylisiä ja eri tekstilajeja edustavia tekstejä. Se antaakin kattavan kuvan kirjoitetusta nyky-yleiskielestä; -ine-sijan käytön vertailu eri teksti- tai tyylilajeissa ei sisälly tämän artikkelin tavoitteisiin. Korpuksen aineisto on morfosyntaktisesti analysoitu automaattisella Functional Dependency Grammar eli FDG-jäsentimellä (Connexor), ja koodatusta aineistosta tehty ContextMillmuotoinen (Virtanen 2000-2003) tietokanta mahdollistaa yksityiskohtaiset haut. Kaikki tässä artikkelissa tekemäni huomiot kielenaineksen (komitatiivisijan, kanssa-postposition, essivisijan) käytöstä suomessa perustuvat tähän aineistoon.

Etenen artikkelissa seuraavasti. Luvussa 2 tarkastelen morfologista produktiivisuutta sekä sen soveltamista sijataivutukseen ja -ine-sijan käytön kuvaukseen (alaluku 2.1). Erikseen esittelen produktiivisuuden jakautumisen tarjoumaan ja toteumaan (alaluku 2.2), joka on avain -ine-komitatiivin produktiivisuuden ytimeen. Luku 3 keskittyy -ine-sijan käyttöön aineistossa, ja lähtökohdaksi otan sen, mitä kirjallisuudessa on esitetty komitatiivin käytön kiteytyneisyydestä. Etsin käytön keskittymiä tarkastelemalla ensin sitä, miten -ine-osumat kumuloituvat lekseemeittäin ja mitä frekventeimmät lekseemit ovat (alaluku 3.1). Tämän jälkeen esitän, miten aineiston tekstiosumat ja lekseemit vastaavat näkemyksiä kiteytyneestä käytöstä (alaluku 3.2), ja osoitan kiteytyneen käytön liittyvän ennen kaikkea kielennettyjen tilanteiden vakiintuneeseen luonteeseen (alaluku 3.3). Luku 4 kokoaa yhteen tulokset ja esittää niistä pohdintoja. 


\section{Morfologinen produktiivisuus}

Komitatiivisijan produktiivisuutta tarkasteltaessa on huomion kohteena morfologinen produktiivisuus. Sitä on määritelty kirjallisuudessa monin eri tavoin. Yksinkertaisimmillaan määriteltynä kielellinen malli on produktiivinen, jos sitä voi soveltaa uusiin yksiköihin (Bybee 2001, 118) ja siten sen avulla voidaan muodostaa uusia kieliopillisia muotoja (Bauer 2001, 2). On siis kyse uusien sanojen muodostamisesta (vrt. Baayen 1993, 183; Bauer 2001, 12-14). Tämän tarkemmasta määritelmästä ei kirjallisuudessa kuitenkaan ole yksimielisyyttä. Rainerin (1987, jota tiivistää Bauer 2001, 25) mukaan produktiivisuutta määritellään kirjallisuudessa kuudella eri tavalla. Määritelmä voi perustua

1. tuotettujen sanojen frekvenssiin (output),

2. mahdollisten sovellettavien sanojen määrään (input),

3. todellisuudessa käytettyjen sanojen ja potentiaalisesti muodostettavissa olevien (potentially created) sanojen suhteeseen,

4. uusien sanojen muodostamisen mahdollisuuteen (possibility of forming),

5. uusien muotojen ilmaantumisen todennäköisyyteen (probability of occurring) tai

6. tiettynä ajanjaksona ilmaantuneiden uusien muotojen määrään.

Määritelmät eivät ole yhteismitallisia, sillä osa niistä on laadullisia ja osa määrällisiä, osa synkronisia ja osa diakronisia, ja osa niistä perustuu olemassaoleviin sanoihin, osa taas potentiaalisiin sanoihin (Bauer 2001, 25). Kun lisäksi eri tutkijat ovat erimielisiä muun muassa frekvenssin ja läpinäkyvyyden roolista produktiivisuudessa, on kirjallisuudessa esitetyistä eri määritelmistä mahdotonta muodostaa yleistystä (vrt. Fernández-Domínguez 2010, 194-195). Yhteistä niille on vain produktiivisuuden yhdistäminen vahvasti sananmuodostukseen. Suurin osa morfologisen produktiivisuuden tutkimuksesta keskittyykin johtamiseen.

Perinteisesti produktiivisuutta pidetään yhtenä tärkeimpänä taivuttamisen ja johtamisen erottelukriteerinä. Pääperiaate on se, että taivutuspäätettä voi soveltaa kaikkiin sanaluokkansa puolesta sopiviin sanoihin ilman rajoituksia, kun taas johtimella voi olla mielivaltaisia rajoitteita. Usein lähdetään siitä, että kaikkien nominien on odotuksenmukaista taipua kaikissa sijoissa, ja jos tähän on poikkeuksia, ne johtuvat sanan perusmerkityksen ja sijamerkityksen yhteensopimattomuudesta, johdoksilla taas voi olla rajoituksia ilman selkeitä semanttisia perusteita. (Haspelmath 2002, 75; ks. myös Hakulinen ym. 2004, 92.)

Osin tämän perusteella olen kuullut esitettävän näkemyksiä, että -ine-muotoa ei edes tulisi pitää sijana vaan ennemmin johtimena. Ovathan infinitiivit ja suuri osa pronomineista rajattuja sen käytön ulkopuolelle ja proprit ovat käytössä harvinaisia, vaikka persoonapronominit ja ihmisten nimet viittaavat nimenomaan komitatiivin primaariosallistujiin, inhimillisiin olioihin. Tämä ei kuitenkaan ole perusteltu näkemys. Ensinnäkin sija määritellään lähtökohtaisesti muodoksi, jolla merkitän substantiivin suhdetta pääsanaansa (Blake 2001, 1) - ja kaikkia suomen substantiiveja voidaan taivuttaa 
komitatiivissa. ${ }^{4}$ Toiseksi maailman kielissä on täysin tavallista, että kaikki nominit eivät taivu symmetrisesti kaikissa sijajärjestelmän sijoissa. Tätä kutsutaan sija-asymmetriaksi, ja yleisimmin taivutuksen yleiskuvasta poikkeavatkin juuri persoonapronominit ja proprit. (Iggesen 2009, 246-247, 249; 2011.) Esimerkiksi uralilaiskielissä pronominien käyttö on paikallissijojen yhteydessä rajallista (vrt. käydä Lassella, mutta $\left.{ }^{\star} k a ̈ y d a ̈ ~ m i n u l l a, ~{ }^{\star} h a ̈ n e l l a ̈\right)$. Onkin selvää, että -ine-komitatiivi on sija ja produktiivisuuden käsitettä on sovellettava sen osalta samoin kuin sijataivutuksen tarkastelussa yleensäkin. Tämä ei kuitenkaan ole yksiselitteistä, kuten seuraavassa alaluvussa nähdään.

\subsection{Käsitteen soveltuminen taivutukseen ja -ine-sijaan}

Vaikka morfologinen produktiivisuus on yhteydessä ennen kaikkea johtamiseen, produktiivisuuden käsite on liitetty myös taivutukseen. Taivutuksessa produktiivisuuden kriteerit eivät kuitenkaan voi olla samat kuin johtamisessa, jos lähtökohdaksi otetaan oletus, että toisin kuin johtimia kaikkia sijoja on odotuksenmukaista soveltaa kaikkiin sanoihin (poislukien edellä esiin tulleet varaukset). Niinpä näkökulma on siirretty sijamuodoista taivutustyyppien produktiivisuuden arviointiin. (Esimerkiksi suomen taivutustyyppien produktiivisuudesta ks. Nikolaev 2011.) Tämä nähdään esimerkiksi Haspelmathilla (2002, luku 7), jonka mukaan produktiivisuus voi tarkoittaa taivutuksen yhteydessä jompaakumpaa seuraavista:

1. taivutustyypin kykyä vetää puoleensa uusia jäseniä ja saada ne vaihtamaan taivutustyyppiä (inflectional class shift) diakronisessa muutoksessa,

2. soveltamista uusiin lekseemeihin, jotka tulevat kieleen joko lainasanoina tai produktiivisten sananmuodostussääntöjen tuottamina uudissanoina.

(Haspelmath 2002, 133; käännös MS-B, korostukset alkuperäiset.)

Haspelmathin kriteerit soveltuvat huonosti -ine-sijan tarkastelun lähtökohdaksi, koska sillä on vain yksi päätevariantti, joka esiintyy samanlaisena kaikissa taivutustyypeissä. Yhden mahdollisen lähestymistavan kriteerien soveltamiseksi suomeen voisi kuitenkin ajatella löytyvän maailman kieliä vertaavan kielitypologisen näkökulman avulla. Kuten johdannossa nähtiin, typologisessa kontekstissa termi komitatiivi viittaa kaikkiin morfologisiin muotoihin, jotka ilmaisevat perusmerkityksenään yhdessäoloa (Stolz ym.

4 Tämän voi osoittaa esimerkiksi epäsanojen avulla, jollaisia perinteisesti käytetään testaamaan morfologista produktiivisuutta. Esimerkiksi seuraavat epäsanat, jotka ovat osa Nikolajevin (2011) epäsanatestiä suomen nominien taivutusjärjestelmän produktiivisuuden kartoittamiseksi, taipuvat poikkeuksetta komitatiivissa: kesu : kesuineen, palso : palsoineen, väätä : väätineen väätäineen, hisi : hisineen $\sim$ hiseineen, koras : koraineen $\sim$ koraksineen $(\sim$ korasineen $)$, ulves $:$ ulveksineen $\sim$ ulveineen $\sim$ ulpeineen. (Taivutustestin teki 16 natiivia Facebookin kautta 6.4.2016. Informantit olivat iältään noin 30-50-vuotiaita, sekä lingvistisen koulutuksen saaneita että maallikoita. Kesu ja palso taipuivat kaikilla informanteilla samoin; muiden kohdalla on annettu kaikki eri -ine-vaihtoehdot yleisyysjärjestyksessään. Vain yhden kerran esiintynyt variantti on sulkeissa.) 
2006; 2009), ja suomessa tällaisia ovat paitsi -ine-sija myös monet adpositiot, yleisimpänä kanssa. Typologiseen määritelmään tukeutuen voisikin ajatella, että suomen komitatiivilla on kaksi pääasiallista muotovarianttia, -ine-sija ja kanssa-postpositio. Näin -ine-muodon produktiivisuutta voisi arvioida tutkimalla, 1) onko diakronisesti tarkasteltuna sanoja, joita olisi alettu käyttää -ine-sijassa kanssa-postpositiorakenteen sijaan, ja 2) käytetäänkö uusia lekseemejä ennemmin komitatiivisijassa kuin kanssa-rakenteen osana. Kansainvälinen komitatiivitutkimus lienee omaksunut tämän näkökulman, kun se olettaa -ine-sijan muuttuneen epäproduktiiviseksi ja alkaneen korvautua kanssa-postpositiolla, joka siten näyttäytyy komitatiivin produktiivisena muotovarianttina (Stolz ym. 2005, 214; 2006, 61).

Lähestymistapaan liittyy kuitenkin kaksi ongelmaa. Ensinnäkin on vaarallista puhua kielen muutoksesta ilman diakronista vertailevaa aineistoa, eikä sellaista ole korvautuvuuspäätelmän tueksi esitetty (esim. Nau 1995, johon Stolz ym. viittaavat kielenmuutoksesta puhuessaan, ei viittaa aineistoon eikä varsinaisesti koko diakroniseen muutokseen). Toinen, perustavanlaatuinen ongelma koskee -ine-sijan ja kanssa-postposition merkityksiä. Jotta yhden muodon käytön perusteella voisi tehdä päätelmiä toisen muodon produktiivisuudesta, lienee välttämätöntä, että muodoilla on yhteinen merkityskenttä. -inesijan ja kanssa-postposition ilmaisemat merkitykset kuitenkin eroavat toisistaan jo itse perusmerkityksen yksityiskohtien osalta ja aivan erityisesti perusmerkityksen ulkopuolella. Komitatiivisijalla voidaan ilmaista monia merkityksiä, joita kanssa-postpositiolla ei ilmaista, ja toisaalta kanssa-postpositiolla on -ine-sijasta poikkeavia käyttötapoja. (SirolaBelliard 2016.) Niinpä muotoja ei voi pitää synonyymisinä eikä toistensa muotovariantteina, ja siten komitatiivisijan produktiivisuuden tarkastelu Haspelmathin tarkoittamalla tavalla osoittautuu mahdottomaksi.

Onkin palattava takaisin ajatukseen odotuksenmukaisuudesta. Se avaa kaksi näkökulmaa, jotka johdattavat -ine-sijan produktiivisuuden ytimeen. Ensimmäinen on -inekomitatiivin vajaakäyttöisyys, siis se, että -ine-sijaa ei voi muodostaa infinitiiveistä eikä kaikista pronomineista. Tämä rikkoo sitä odotusta vastaan, että kaikki nominit taipuisivat kaikissa sijoissa. Edellä kuitenkin on osoitettu, ettei nominien kategoria ole oikea lähtökohta käytön laajuuden arviointiin ja että maailman kielten sijasysteemeille on tyypillistä epäsymmetrisyys. Sijamuodon ei siis tarvitse soveltua kaikkiin nomineihin ollakseen produktiivinen. Toinen näkökulma koskee -ine-sijalle mahdollisen käytön laajuutta. Vaikka kaikkia substantiiveja (sekä numeraaleja ja adjektiiveja) voi taivuttaa komitatiivissa, se ei ole kieliyhteisössä odotuksenmukaista. Tästä kertovat niin sijan pieni tekstifrekvenssi, kirjallisuuden luonnehdinnat käytön kiteytyneisyydestä, kielenkäyttäjien - niin lingvistien kuin maallikoiden - huomautukset siitä, että -ine-sijaa käytetään hyvin vähän jos lainkaan, kuin lopulta komitatiivin eksplisiittinen nimeäminen epäproduktiiviseksi sijaksi.

Näissä kahdessa näkökulmassa kiteytyy kysymys, mikä on produktiivisuuden kannalta tärkeämpää: se, että tietystä sanasta voi muodostaa jonkin muodon (kuten komitatiivin), vai se, että kielenkäyttäjä todella muodostaa sen. Seuraavassa alaluvussa tarkastellaan Bauerin (2001) tarjoamia välineitä kysymyksen ratkaisuun. 


\subsection{Tarjouma ja toteuma}

Bauer antaa produktiivisuudelle seuraavan kaksijakoisen määritelmän:

'Productivity' deals with the number of new words that can be coined using a particular morphological process, and is ambiguous between the sense 'availability' and the sense 'profitability' (Bauer 2001, 211).

Bauerin mukaan (2001, 205-206) morfologinen produktiivisuus voidaan jakaa kahteen erilliseen alueeseen, tarjoumaan (availability) ja toteumaan (profitability) ${ }^{5}$. Ensimmäinen näistä keskittyy kysymykseen, mitä voi muodostaa, ja jälkimmäinen siihen, mitä todellisuudessa muodostetaan. Kielen jakautuminen kahteen ei toki ole yksin Bauerin ajatus, vaan samantyyppinen kahtiajako löytyy esimerkiksi Coseriun (1975) systeemin ja normin käsitteistä tai saksalaisessa lingvistisessä perinteessä käytetyistä potentiaalisen ja aktuaalisen käsitteistä. Bauerin sovellus on kuitenkin suoraan käyttökelpoisin -ine-sijan tarkasteluun.

Tarjouma on se produktiivisuuden ulottuvuus, jota suurin osa produktiivisuuden tutkimuksesta käsittelee ja jota useimmat produktiivisuuden määritelmät koskevat: morfologinen prosessi on tarjolla, jos sen avulla voidaan muodostaa uusia sanoja. Tarjouma on siis morfologisen prosessin potentiaali morfologiseen, toistettavissa olevaan muodostukseen (Bauer 2001, 98, 211; vrt. produktiivisuuden käsitteeseen, mm. Bybee 2001; Baayen 1993, 183; Haspelmath 2002, 98). Tarjouma on binaarinen ulottuvuus, siten että morfologinen prosessi joko on tarjolla tai ei ole. Esimerkiksi suomen - nti-johdin on tarjolla -Oi-loppuisille verbeille (kuten tapetoida > tapetointi), mutta se ei ole tarjolla supistumaverbeille (kuten hypätä > *hyppäynti/hyppäänti/hypynti/...). Sen sijaan esimerkiksi -minen-johdin on tarjolla myös supistumaverbeille. Tarjouma määräytyykin kielisysteemin rajoitusten perusteella, ja -ine-sijan vajaakäyttöisyydessä ${ }^{6}$ on paljolti kyse sen tarjoumaan liittyvistä rajoituksista. Esimerkiksi infinitiiveille se ei ole tarjolla (kuten hyppäämä- > `hyppäämäineen, vrt. esim. hyppäämättä). (Persoonapronominien käyttörajoitus vaikuttaa kuitenkin enemmän syntaktiselta tai pragmaattiselta kuin tarjouman rajoitukselta, sillä substantiivisesti käytetyt satunnaismuodosteet kuten minuineen, hänineen tai teinesi ovat mahdollisia, ks. Sirola-Belliard 2016, 182-183, 185-186.)

Toteuma on jatkumollinen ulottuvuus, joka kuvaa sitä, kuinka laajasti tarjolla olevaa morfologista prosessia kielessä hyödynnetään. Se, että tietty morfologinen prosessi on tarjolla, ei vielä tarkoita, että sitä myös käytetään - kaikki mahdolliset sanat eivät ole yhtä todennäköisiä. Toteumaan voivat vaikuttaa yllättävätkin systeemin ulkopuoliset tekijät (toteumaa rajoittavista tekijöistä, ks. Bauer 2001, 126-143, 207-209). Lukuisat

5 Kiitän Kari Hiltulaa termiparin suomennoksesta.

6 Termi vajaakäyttöinen sija esiintyy esimerkiksi Isossa suomen kieliopissa (Hakulinen ym. 2004, 12081209). Perinteisesti komitatiivia on yhdessä abessiivin ja instrumentaalin kanssa nimitetty marginaalisiksi sijoiksi. 
pyrkimykset mitata produktiivisuuden astetta ( $\mathrm{mm}$. Baayenin tutkimukset) käsittelevät produktiivisuutta nimenomaan toteuman näkökulmasta. (Yhteenveto produktiivisuuden asteen tutkimuksista, ks. Plag 1999, 22-34; Bauer 2001, 143-161.)

Toteumaa voidaan edelleen tarkastella kahdessa eri ulottuvuudessa, yhtäältä tekstifrekvenssin (token $\sim$ text frequency) ja toisaalta lekseemiesiintymien (type $\sim$ lexical frequency) kannalta. Tekstifrekvenssi kertoo, montako kertaa tiettyä morfologista prosessia tietyssä tekstissä käytetään, esimerkiksi montako kertaa tekstissä tulee vastaan komitatiivisijainen sana. Lekseemiesiintymien ulottuvuudessa tarkastellaan sitä, moneenko eri lekseemiin tiettyä morfologista prosessia on tekstissä sovellettu. Komitatiivin osalta kyse on siitä, montako eri lekseemiä tekstissä on taivutettu komitatiivissa.

Produktiivisuuden jakaminen kahteen tarkastelu-ulottuvuuteen auttaa jäsentämään komitatiivisijan produktiivisuudessa sitä, mikä aluksi tuntui ristiriitaiselta. Tarjouman näkökulmasta -ine on produktiivinen niistä sanoista, joille se on tarjolla - siis substantiiveista, adjektiiveista ja numeraaleista sekä osasta pronomineja ${ }^{7}$. Bauer $(2001,205)$ on hyvin eksplisiittinen sen suhteen, että yhtäältä prosessi joko on tai ei ole tarjolla mutta toisaalta tarjoumaa voidaan tarkastella hyvinkin rajatuin ehdoin. Komitatiivin produktiivisuuden kannalta tarjouman tarkastelu ei vie pitkälle, vaan huomio on keskitettävä komitatiivin toteumaan, johon siirrytään seuraavassa luvussa.

\section{Komitatiivisijan kiteytyneisyys HS20oo-korpuksessa}

Komitatiivin toteumasta, kuten -ine-komitatiivista ylipäätään, on kirjoitettu varsin vähän (kattavin käytön kuvaus lienee Penttilän vuoden 1957 kieliopissa). Frekvenssin osalta tiedetään, että komitatiivi on sijoista vähiten käytetty (Hakulinen ym. 2004, 1179; Ikola 1999; Pajunen 2010, 492-493). Sen sijaan lekseemiesiintymien tasoa ei ilmeisesti ole tutkittu. Siitä huolimatta vallalla on käsitys, että -ine-sijan käyttö on fraasiutunutta, kiteytynyttä tai vakiintunutta. Esimerkiksi Vilkuna arvioi lauseopissaan suomen marginaalisten sijojen eli komitatiivin, abessiivin ja instruktiivin olevan "NP:issä harvinaisia, melkeinpä vain joihinkin fraaseihin kuuluvia" (Vilkuna 2000, 81, korostus MS-B). ${ }^{8}$ Käännöskieltä

7 Iso suomen kielioppi määrittelee komitatiivin tarjoumaksi substantiivit ja adjektiivit sekä monikolliset demonstratiivipronominit silloin, kun komitatiivi esiintyy substantiivin määreessä (Hakulinen ym. 2004, 1211). HS200o-korpuksessa on kuitenkin myös 50 osumaa komitatiivisijaisista numeraaleista: kymmenestä kardinaaliluvusta muodostettuja (14 osumaa kaksine-komitatiivista, 7 kolmine, 1 neljine, 1 viisine, 1 yhdeksine, 3 kymmenine, 12 satoine, 6 tuhansine, 3 miljoonine, 1 miljardeine) ja yhdestä ordinaaliluvusta muodostettu (1 osuma toisine-komitatiivista). Lisäksi HS20oo sisältää komitatiiviosumia myös muista pronomineista kuin ISK:n mainitsemista monikollisista demonstratiivipronomineista: attribuutteina esiintyvät myös eräine, kaikkine, monine, muine, muutamine ja useine sekä näistä kaksi lisäksi possessiivisuffiksellisina (kaikkineen, 82 osumaa, ja kaikkinensa, 13 osumaa, sekä muineen, jolla on 2 osumaa rakenteessa $N$-COM-Poss sun muineen).

8 Vilkuna jatkaa: "Abessiivi ja instruktiivi ovat kuitenkin kaukana marginaalisesta infiniittimuotoihin liittyessään (...)" (Vilkuna 2000, 81), mikä vahvistaa edelleen käsitystä juuri komitatiivin marginaalisesta, fraasiutuneesta käytöstä. 
tarkastelevassa artikkelissaan Eskola ja Tommola (2000) kuvaavat komitatiivin käytön suomessa seuraavasti:

Komitatiivin käyttö on hyvin fraasiutunutta ja liittyy usein tiettyihin sanoihin (esim. vaimoineen, lapsineen, seurueineen, seuralaisineen) tai enemmän tai vähemmän kiteytynyttä, jolloin vakiintunut muoto on nimenomaan komitatiivi (esim. korkoineen, juurineen, kuorineen, höysteineen). Hyvin tyypillinen komitatiivin käyttötapa on myös ns. emfaattinen komitatiivi, jolla tarkoitetaan vakiintuneen vahvistussanan (kaikkine, kaikkineen, päivineen, poikineen) sisältäviä komitatiivimuotoja, jotka vahvistavat ilmauksen kokonaisvaltaisuutta. (Eskola-Tommola 2000, 97; lihavoinnit MS-B.)

Näkemys komitatiivin käytön marginaalisesta, fraasiutuneesta luonteesta esiintyy myös ei-kielitieteellisessä keskustelussa (esim. Korpela 2004-2015, s.v. komitatiivi; Wikipedia, s.v. komitatiivi), missä esimerkkeinä kiteytyneistä sanonnoista on mainittu (edeltävässä lainauksessa esille tulleiden lisäksi) mm. perheineen, ympäristöineen ja liitteineen, niine hyvineen ja omin nokkineen sekä toistomuotoinen kimpsuineen ja kampsuineen.

Kirjallisuudessa 'fraasiutunut', 'kiteytynyt' ja 'vakiintunut' tuntuvat olevan synonyymisessä käytössä ja tarkoittavan jonkinlaista "tavanomaista käyttöä" tai pikemmin leksikaalista keskittymistä. Bauerin termein voisi ajatella, että komitatiivisijan tarjouman esitetään rajoittuvan vain joihinkin tavanomaisiin sanoihin. Tämä taas kertoo oletuksesta, että komitatiivi olisi vain vähän produktiivinen, ellei jopa epäproduktiivinen.

Komitatiivin todellinen käyttö kuitenkin osoittaa oletuksen liioitelluksi. Tämä nähdään seuraavissa alaluvuissa, joiden käsittely perustuu HS200o-korpuksen komitatiivisijassa taipuviin possessiivisuffiksillisiin substantiiveihin ${ }^{9}$. Niillä on koko korpuksessa yhteensä 5619 osumaa, joiden joukossa on 2830 eri lekseemiesiintymää. Näiden perusteella esitän -ine-sijan kiteytyneisyyteen kaksi näkökulmaa. Ensimmäinen on osumien kumuloituminen eri lekseemeihin, minkä avulla voidaan hahmottaa kiteytyneen käytön linjoja, ja toisena kiteytyneen käytön leksikaalinen puoli: millaista ja paljonko sitä on, miten se jakautuu korpuksessa sekä mitä sen ulkopuolelle jää.

\subsection{Osumien kumuloituminen lekseemeittäin}

Korpuksen komitatiiviosumien jakautuminen eri lekseemeille antaa viitteitä käytön kiteytyneistä keskittymistä. Osumat kumuloituvat lekseemeittäin epätasaisesti, siten että yhtäältä yleisimmin komitatiivissa esiintyville lekseemeille keskittyy huomattavan paljon osumia ja toisaalta vain kerran esiintyviä sanoja on paljon - kolme neljäsosaa korpuksen

9 Korpuksessa on myös komitatiivisijaisia adjektiiveja, numeraaleja ja pronomineja, joilla on koko korpuksessa yhteensä n. 650 osumaa ja näiden joukossa n. 400 eri lekseemiä. Jätän kuitenkin attribuutit tämän käsittelyn ulkopuolelle, sillä myös kirjallisuuden kiteytyneisyysväitteet keskittyvät possessiivisuffiksillisiin substantiiveihin. Siten viittaan komitatiivilekseemeillä 2830 :een korpuksen N-COMPoss -lekseemiin ja komitatiiviosumilla näiden 5619 osumaan. 


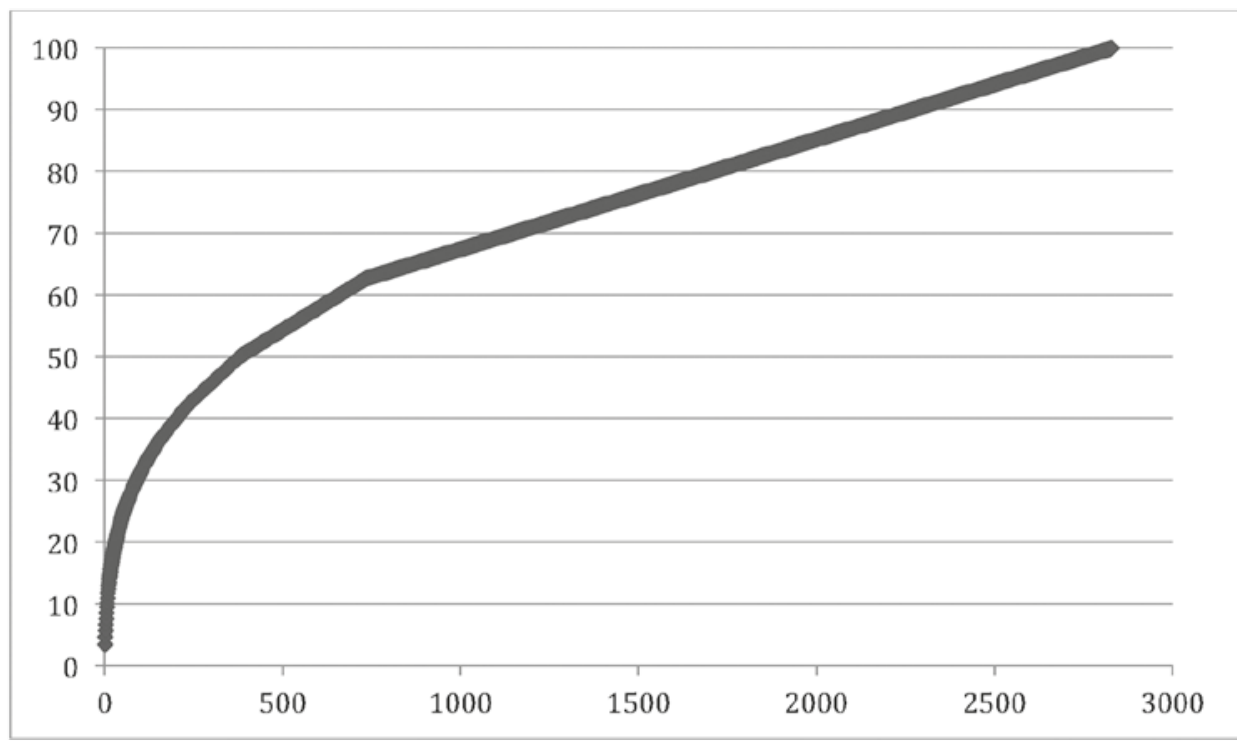

Kuva 1. Komitatiiviosumien suhteellinen kumuloituminen lekseemeittäin HS20ookorpuksessa (lekseemejä 2830 , osumia 5619 ).

-ine-sijassa esiintyvistä lekseemeistä (ks. kuva 1). Yleisin $5 \%$ lekseemeistä kattaa $35 \%$ osumista ja yleisin $20 \%$ lekseemeistä kattaa $56 \%$ osumista. Tämän voisi ajatella tukevan oletusta, että -ine-sijan käyttö on lähtökohtaisesti kiteytynyttä.

Kyse on kuitenkin kielen sanaston tyypillisestä käyttäytymisestä, jossa hyvin pienellä joukolla lekseemejä on hyvin paljon käyttöä ja harvoin käytettyjä sanoja on määrällisesti hyvin paljon. Tämä näkyy esimerkiksi suomen verbisanastossa (Pajunen 2006) tai sanomalehtikielen substantiiveissa yleisesti (Taajuussanasto 9996) ${ }^{10}$. Niinpä se, että jotkin tietyt lekseemit ovat tyypillisiä -ine-sijassa, ei tarkoita, että komitatiivin käyttö olisi niihin kiteytynyt. Erityisen hyvin tämän osoittaa komitatiiviosumien vertailu esimerkiksi essiivissä taipuviin HS200o-korpuksen substantiiveihin ${ }^{11}$. Yleisimmät essiivissä taipuvat substantiivilekseemit nimittäin kattavat komitatiiviakin suuremman osan osumista (ks. essiiviosumien kumuloitumisesta kuva 2): yleisin $5 \%$ lekseemeistä kattaa $79 \%$ osumista ja yleisin $20 \%$ lekseemeistä $89 \%$ osumista. Vain kerran esiintyviä sanoja lekseemeistä on kaksi kolmannesta. Kukaan ei kuitenkaan ole esittänyt, että essiivi olisi toteumaltaan epäproduktiivinen tai käytöltään kiteytynyt sija.

10 Taajuussanastoon on vuonna 2004 koottu sanomalehtikielen yleisimmät 9996 lekseemiä, joista substantiiveja on 4467 ja niillä 13453729 osumaa. Näiden suhteellinen kumuloituminen muistuttaa -ine-osumien kumuloitumista HS2000-korpuksessa: yleisin $5 \%$ lekseemeistä kattaa $44 \%$ osumista ja yleisin $20 \%$ lekseemeistä kattaa $72 \%$ osumista.

11 Koko HS200o-korpuksessa on lähes 200000 essiivisijaista substantiiviosumaa. Näistä ensimmäisen 63000 osuman joukossa (taulukkotekninen käytännön rajaus) on yhteensä 7505 eri lekseemiä. 


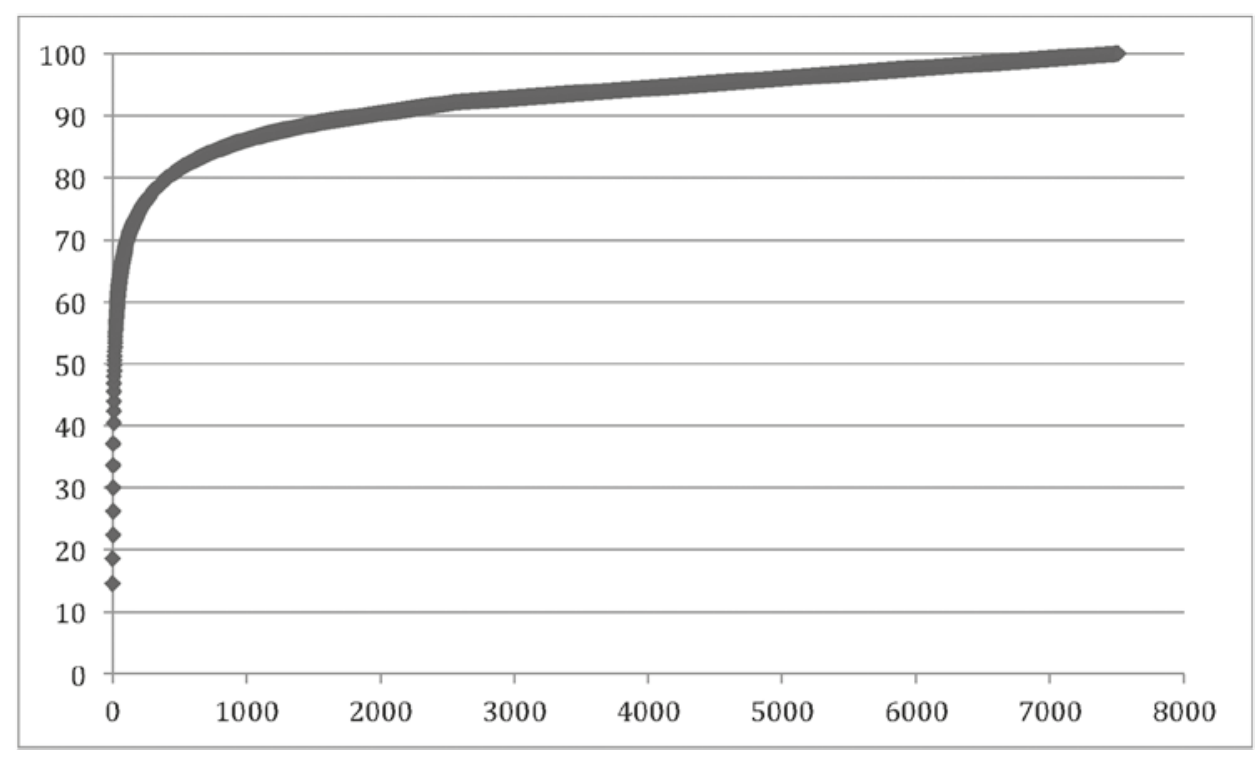

Kuva 2. Essiiviosumien suhteellinen kumuloituminen lekseemeittäin HS20oo-korpuksessa (otoksessa lekseemejä 7 505, osumia 63 0oo).

On selvää, että kaikkein frekventeimpiä käyttöjä voi pitää kiteytyneinä. Kahdenkymmenen yleisimmän komitatiivisijaisen lekseemin joukkoon sisältyy puolet edellä esiin tulleista kirjallisuudessa mainituista komitatiiveista (yleisyysjärjestyksessään perheineen, korkoineen, lapsineen, (X:ineen) kaikkineen, vaimoineen, seurueineen, juurineen ja ympäristöineen). Tämäntyyppinen kiteytyneisyys ei kuitenkaan ole -ine-sijan erityispiirre, vaan yhtä lailla kiteytyneitä ovat frekventeimmät essiivissä taipuvat lekseemit. Korpuksen yleisimmät essiivilekseemit ovat vuosi (yksikkö- ja monikkomuodot yhteensä $15 \%$ osumista; vrt. yleisin komitatiivi perheineen kattaa $3 \%$ osumista) sekä kaikki viikonpäivät (kukin 3-4 \%; nämä kahdeksan yleisintä lekseemiä näkyvät erillisinä pisteinä kumuloituvien osumien kuvaajassa, ks. kuva 2). Kahdenkymmenen yleisimmän essiivilekseemin joukossa on muiden ajanmääreiden (yleisyysjärjestyksessään lekseemit päivä, aika, kesä, viikonloppu, syksy, kevät ja yö) lisäksi kivettynyt kokonaan-muoto sekä abstraktilekseemit tavoite, tarkoitus, syy ja seuraus. Essiiviä tutkinut Hynönen $(2013 ; 2016)$ on todennut saman kiteytyneisyyden Lauseopin arkiston aineiston perusteella. Runsas 1/3 essiivilausekkeista ilmaisee olotilaa, kaikki loput ovat käytöltään kiteytyneitä ajan- ja paikanilmauksia, ja myös olotilanilmauksissa on kiteytyneitä keskittymiä (kuten vanhana, nuorena, 10-vuotiaana).

Useiden osumien keskittyminen joihinkin tiettyihin lekseemeihin ei siis kerro komitatiivisijan epäproduktiivisuudesta vaan kielen luonteesta yleensä. Se, mikä vertailussa essiiviin nouseekin tämän yleistendenssin toteamista mielenkiintoisemmaksi, on lekseemien ja osumien määrän suhde. Essiivin tekstifrekvenssi on luonnollisesti komitatiivin tekstifrekvenssiä suurempi, korpuksessa 43-kertainen (6,38 N-ESs /100o tekstisanaa vs. 
0,15 N-COM-POss / 1000 tekstisanaa), mutta komitatiivilla on sen sijaan essiiviä suurempi lekseemitiheys. Osumiin suhteutettuna on komitatiivissa taipuvia eri substantiiveja korpuksessa enemmän kuin essiivissä taipuvia, ja siis jokaisella essiivissä taipuvalla substantiivilekseemillä on keskimäärin enemmän osumia kuin komitatiivilekseemeillä (N-ESs: n. 7 osumaa / lekseemi vs. N-COM-Poss: 2 osumaa / lekseemi). Tämä tarkoittaa sitä, että komitatiiviosumien joukossa on enemmän leksikaalista variaatiota kuin essiivillä, vaikka komitatiivilla onkin pieni tekstifrekvenssi. Tämä puolestaan voidaan tulkita niin, että komitatiivin toteuma on jopa produktiivisempi kuin essiivin.

\subsection{Kiteytyneen käytön tyypit ja yleisyys}

Sitä, kuinka suuri osa -ine-sijan käytöstä todellisuudessa vastaa oletusta kiteytyneestä käytöstä ja millaista kiteytynyt käyttö on, voidaan lähestyä komitatiiveista annettujen esimerkkien avulla. Alla esitän kirjallisuudesta (Eskola-Tommola 2000; Vilkuna 2000; Korpela 2004-2015; Wikipedia) löytyneet kahdeksantoista esimerkkiä kiteytyneistä tai fraasiutuneista komitatiivimuodoista (ks. taulukko 1, jossa $n=$ kunkin lekseemin tai lekseemiparin osumamäärä korpuksessa, $\%$ = osumien osuus korpuksen komitatiiviosumista; attribuutille kaikkine ei ole laskettu suhteellista osuutta, koska se ei kuulu tarkastelun alla oleviin substantiivilekseemeihin, eikä sitä myöskään lasketa mukaan osumien kokonaismäärään). Kahta lukuunottamatta (höysteineen, kimpsuineen [ja kampsuineen]) ne esiintyvät kaikki korpuksessa.

Taulukko 1. Kirjallisuuden esimerkit komitatiivin kiteytyneestä käytöstä ja niiden esiintyminen HS200o-korpuksessa.

\begin{tabular}{|l|l|l|l|l|l|}
\hline komitatiivi & $\mathbf{n}$ & $\mathbf{\%}$ & komitatiivi & $\mathbf{n}$ & $\%$ \\
\hline perheineen & 196 & $3,5 \%$ & kuorineen & 13 & $0,2 \%$ \\
\hline korkoineen & 68 & $1,2 \%$ & liitteineen & 9 & $0,2 \%$ \\
\hline lapsineen & 57 & $1,0 \%$ & irtaimistoineen & 8 & $0,1 \%$ \\
\hline kaikkineen (emf.) & 42 & $0,8 \%$ & omin(e) nokkineen & 6 & $0,1 \%$ \\
\hline kaikkine (emf. attr.) & $(39)$ & & seuralaisineen & 3 & $0,05 \%$ \\
\hline vaimoineen & 38 & $0,7 \%$ & poikineen (emf.) & 2 & $0,05 \%$ \\
\hline seurueineen & 30 & $0,5 \%$ & niine hyvineen & 1 & $0 \%$ \\
\hline juurineen & 29 & $0,5 \%$ & höysteineen & 0 & $0 \%$ \\
\hline ympäristöineen & 27 & $0,5 \%$ & kimpsuineen (ja kampsuineen) & 0 & $0 \%$ \\
\hline päivineen $(\mathrm{emf})$ & 18 & $0,3 \%$ & yhteensä & 547 & $9,7 \%$ \\
\hline
\end{tabular}

Esimerkkien joukosta voi kiinnittää erikseen huomiota emfaattiseen komitatiiviin (kirjallisuuden mainintojen perusteella merkitty taulukkoon "emf."). Sillä tarkoitetaan ilmauksia, joissa komitatiivisijaiseen substantiiviin liittyy vahvistava kaikkineen, päivineen tai poikineen (esimerkiksi virheineen kaikkineen, karvoineen päivineen tai pullo poikineen). Eskola ja Tommola $(2000,97)$ laskevat emfaattiseksi myös ne komitatiivit, joilla on attribuuttinaan 
kaikkine (esimerkiksi kaikkine kuluineen). Emfaattinen komitatiivi on ainoa Ison suomen kieliopin erikseen mainitsema komitatiivisijan käytön erikoistapaus (Hakulinen ym. 2004, 1212), ja Eskolan ja Tommolan $(2000,97)$ mukaan se on "[h]yvin tyypillinen komitatiivin käyttötapa". HS200o-korpuksessa näitä on kuitenkin vähän, vain $1 \%$ kaikista komitatiiviosumista (käytöstä ks. tarkemmin Sirola-Belliard 2016, 250-259). Korpus osoittaakin, ettei emfaattinen komitatiivi ole muuhun -ine-sijan käyttöön verrattuna niin yleinen kuin on ajateltu. Toisaalta on mahdollista, että se on ominainen enemmänkin puhutulle kuin kirjoitetulle kielelle. Tähän antaa viitteitä kuulonvaraisesti poimimani komitatiivin vertailuaineisto, mutta suurten suomen puhekielen aineistojen puuttuessa asiaa ei toistaiseksi voi todentaa. On kuitenkin selvää, että emfaattista komitatiivia voi pitää nimenomaan komitatiivin fraasimaisena käyttönä, ja seuraavassa niin tehdäänkin.

Kiteytyneen käytön laajuuden selvittämisessä lähtökohtana ovat kirjallisuudessa esitetyt konkreettiset esimerkit kiteytyneistä komitatiivimuodoista. Korpuksen kymmenen yleisimmän komitatiivissa taipuvan lekseemin joukossa on niistä viisi, viidentoista yleisimmän joukossa yhdeksän ja 40 yleisimmän joukossa yksitoista. Kaikki ne yhdessä kattavat $10 \%$ korpuksen komitatiiviosumista (ks. taulukko 1). Koska kyseessä ovat kuitenkin nimenomaan esimerkit kiteytyneistä muodoista, tulee koko kiteytyneen käytön laajuuden kartoittamiseksi hahmotella esimerkkejä yleisemmät merkitystyypit tai käyttöluokat, jotka kuvaavat kiteytynyttä käyttöä. Kirjallisuuden esimerkit voidaankin ryhmitellä merkityksensä perusteella seuraavaan viiteen luokkaan, joiden perusteella on mahdollista tarkastella kiteytyneen käytön kokonaislaajuutta korpuksessa.
a. läheiset ihmissuhteet (vaimo, lapsi, perhe)
b. yleisempi seuralaisuuden ilmaus, "et al" (seurue, seuralainen)
c. inherentit osa-kokonaisuus-suhteen sekä 'mukaan lukien' -merkityksen ilmaisut (juuri, kuori, korko, irtaimisto, liite, höyste, ympäristö)
d. vahvistavat komitatiivit (kaikkineen, päivineen, poikineen)
e. kiteytyneet sanaparit [varsinaiset fraasiutuneet komitatiivit] (niine hyvineen, omin nokkineen; kimpsuineen ja kampsuineen)

Kiteytyneen käytön luokat jakautuvat käytön motivaation perusteella kahteen ryhmään. Ensinnäkin varsinaista fraasimaista käyttöä edustavat kohdat d ja e: vahvistavat kaikkineen, päivineen ja poikineen sekä idiomaattiset niine hyvineen, omin nokkineen $\sim$ nokkinensa ja kimpsuineen ja kampsuineen. Nämä nimenomaiset ilmaukset myös kattavat pitkälti kaiken korpuksesta löytyvän fraasimaisen käytön, joka on kokonaisuudessaan vähäistä. Fraasikäytössä on korpuksessa seitsemän eri ilmaisua, nimittäin edellä mainitut (lukuunottamatta kimpsuineen ja kampsuineen -ilmausta) sekä lisäksi sun muineen ja omin(e) lupineen lupi$n e n s a$, ja näillä on yhteensä 76 osumaa. Toiseksi kaikkia muita kiteytyneitä komitatiiveja (kohdat a-c) voi fraasimaisuuden sijaan pitää tilanteisesti motivoituina. Ne kielentävät kulttuurisesti konventionaalisia tilanteita: sitä, kenen tai keiden kanssa tavallisesti ollaan ja toimitaan, ja sitä, millaisia osia konventionaalisiin kokonaisuuksiin kuuluu. Merkitystyypiltään vastaavia ilmauksia löytyy korpuksesta runsaasti lisää. 
Olen analysoinut koko HS2000-aineiston merkitysluokkien (a-e) perusteella, ja näitä luokkia vastaa $28 \%$ kaikista komitatiiviosumista. Tästä voi tehdä yleistyksen, että komitatiivin käytöstä reilua neljännestä voidaan leksikaalisen sisältönsä puolesta pitää kiteytyneenä. Yhteen lukuun yleistäminen ei kuitenkaan anna tarkkaa kuvaa -ine-sijan käytöstä tai kerro sijan produktiivisuudesta. Käyttöfrekvensseihin perustuvassa lähemmässä tarkastelussa sen sijaan nähdään, että juuri kiteytyneen käytön jakautuminen korpuksessa valaisee komitatiivin produktiivisuuden luonnetta. Komitatiivisijassa nimittäin yhdistyvät sekä produktiivisen (suurella määrällä komitatiivilekseemejä on hyvin vähän osumia) että epäproduktiivisen (pienellä määrällä komitatiivilekseemejä on paljon osumia) kategorian kriteerit sen mukaisesti kuin Baayen ne määrittelee:

The importance of type frequency emerges even more clearly when it is pitted against token frequency. Productive categories are characterized by the presence of large numbers of low-frequency forms, whereas unproductive categories tend to contain many high-frequency forms (...)." (Baayen 2009, luku 3.2.1)

Lähempää tarkastelua varten olen jakanut HS2000-korpuksen lekseemiesiintymät ryhmiin osumien tekstifrekvenssin perusteella. Ryhmittelyn lähtökohtana ovat osumamääriltään tasakokoiset luokat, mutta lopulliset luokat ovat keskenään osin erisuuruiset, sillä kaikki yhtä monta kertaa korpuksessa esiintyvät lekseemit on sijoitettu yhteen luokkaan. Tällä tavoin jaoteltuna korpuksen 5619 osumaa voidaan jakaa lekseemeittäin neljään luokkaan (ks. kuva 3). Oman luokkansa (D) muodostavat kaikki yhden kerran korpuksessa -ine-sijassa esiintyvät lekseemit eli hapax legomenon (HL) -komitatiivit, joita on 2 094. Jäljelle jäävät lekseemit jakautuvat kolmeen osumiltaan mahdollisimman tasasuureen luokkaan (A: yhdellä lekseemillä on 14-196 osumaa, B: 4-13, C: 2-3).

Kun komitatiivilekseemejä tarkastellaan näin osumafrekvenssiensä mukaan, nähdään selvästi, miten komitatiivin kiteytynyt käyttö keskittyy frekventeimpien lekseemien luokkaan. A-luokan osumista 85:tä prosenttia voidaan pitää kiteytyneinä, B-luokasta neljäsosaa, C-luokasta enää kymmentä prosenttia ja HL-lekseemeistä kuutta prosenttia. Näissä erityisesti viimeisten luokkien kohdalla on kiteytyneisyyden rajoja tarkoituksella venytetty äärimmilleen. Esimerkiksi läheisten ihmissuhteiden ilmauksiin on hyväksytty muun muassa eukkoineen, nuorikkoineen, pirttihirmuineen, siippoineen ja jopa latinouroksineen, joita ei voi pitää ennalta-arvattavina ja siten leksikaalisesti kiteytyneinä mutta jotka viittaavat yhdessäolosuhteen tilanteisesti vakiintuneeseen osapuoleen, elämänkumppaniin. Näin tuloksessa voidaan huomioida käytön mahdollinen tilannesidonnaisuus myös vähäkäyttöisten lekseemien kohdalla.

Aineisto osoittaa, että käsitys komitatiivin käytön kiteytyneisyydestä pitää paikkansa - osittain, kaikkein frekventeimpien komitatiivi-ilmausten osalta. Havainnollistukseksi esimerkissä 4 luetellaan yleisyysjärjestyksessä kaikki A- ja B-luokkien lekseemit, jotka sopivat kirjallisuuden perusteella hahmottuviin merkitystyyppeihin (a-e). 


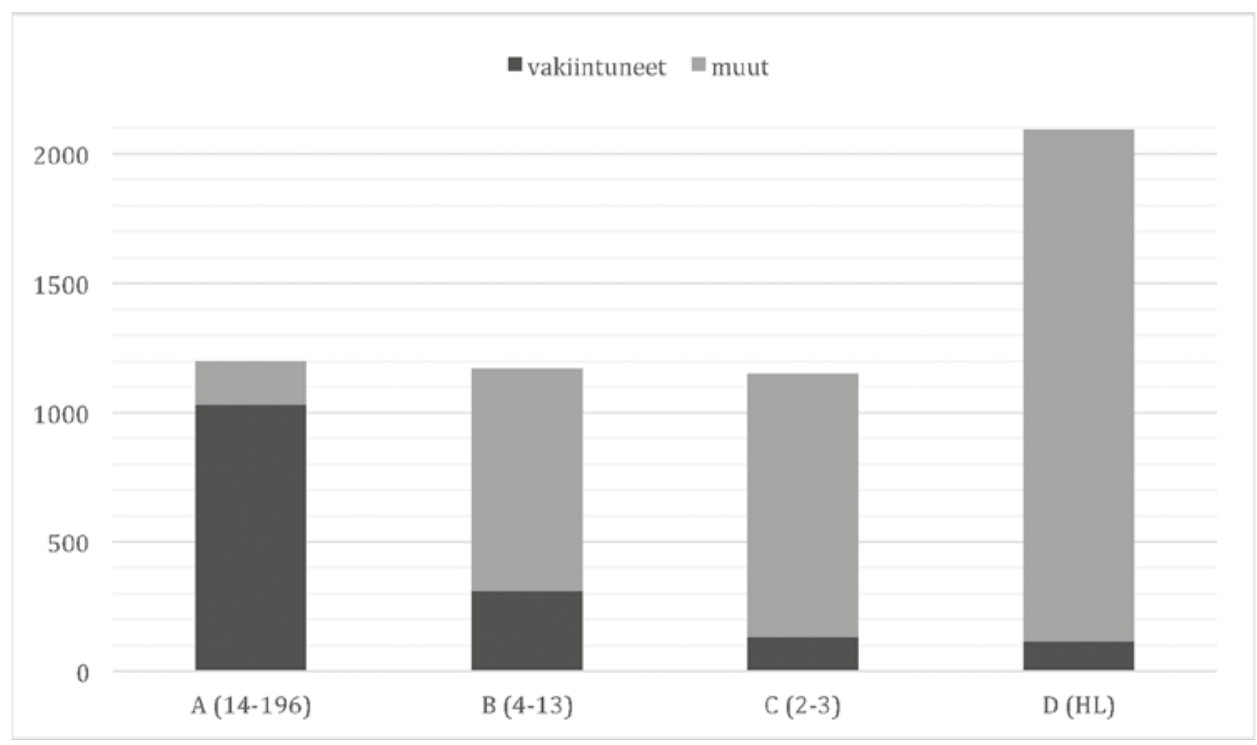

Kuva 3. HS20oo-korpuksen komitatiiviosumat lekseemiluokittain $(\mathrm{n}=5619)$.

(4) a. läheiset ihmissuhteet: (A) perheineen, lapsineen, ystävineen, vaimoineen, puolisoineen, vieraineen, kavereineen, vanhempineen, koirineen, miehineen, tovereineen; (B) (leksikaalisesti käytetty) poikineen, lemmikkeineen, rouvineen, tyttärineen, valmentajineen, isäntineen, poikasineen, sukulaisineen, äiteineen

b. yleisempi seuralaisuuden ilmaus: (A) yhtyeineen, joukkoineen, kumppaneineen, seurueineen, ryhmineen, avustajineen, orkestereineen, kollegoineen, työryhmineen, liittolaisineen, työtovereineen; (B) miehistöineen, joukkuetovereineen, hallituksineen, trioineen, yhteistyökumppaneineen, apulaisineen, bändeineen, kannattajineen, esikuntineen, saattajineen, taustavoimineen, puolueineen, taustajoukkoineen, tukijoineen, tutkimusryhmineen, virkamiehineen, apureineen, jäsenjärjestöineen, kuoroineen, kuvausryhmineen, kvintetteineen, retkikuntineen, tukijoukkoineen, tutkijaryhmineen, tytäryhtiöineen

c. inherentti osa-kokonaisuus-suhde ja 'mukaan lukien': (A) korkoineen, juurineen, ympäristöineen, arvonlisäveroineen; (B) kuorineen, lähialueineen, liitteineen, irtaimistoineen, lisineen, kalusteineen, kuluineen, lisäkkeineen, varsineen, lähiympäristöineen, veroineen, korotuksineen, viivästyskorkoineen

d. vahvistavat komitatiivit: (A) (X:ineen) kaikkineen, (X:ineen) päivineen

e. kiteytyneet sanaparit: (B) (omin) lupineen, (omin) nokkineen

Edellä on tarkasteltu komitatiiviosumia, ja seuraavaksi keskitytään kiteytyneen käytön osuuteen lekseemeistä (ks. kuva 4). Niistä kiteytyneen käytön osuus on jokseenkin 


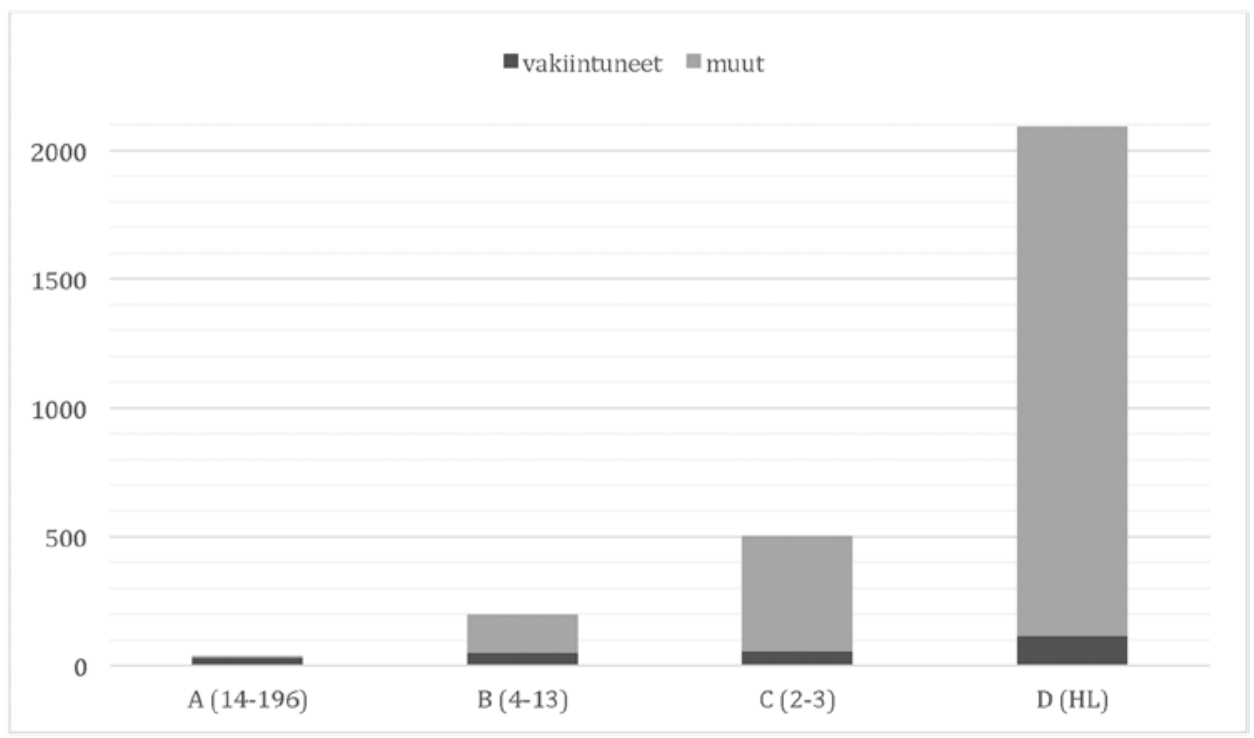

Kuva 4. HS20oo-korpuksen komitatiivilekseemit lekseemiluokittain $(\mathrm{n}=2830)$.

sama kuin osumissa: A-luokassa lekseemeistä kiteytyneitä on 78 \% (kiteytyneiden ulkopuolelle jää kahdeksan lekseemiä: teksti, rakennus, auto, kuva, kamera, laite, varuste ja ongelma), B-luokasta neljäsosa, C-luokasta kymmenesosa ja D-luokasta $6 \%$. Oleellinen ero on kuitenkin luokkien koossa. Osumia luokissa on tasaisesti, mutta frekventin käytön luokissa lekseemejä on hyvin vähän ja pääosa lekseemeistä kuuluu HL-lekseemien luokkaan. ${ }^{12}$ Niinpä kiteytyneiden lekseemien osuus kaikista komitatiivilekseemeistä jää pieneksi, yhteen kymmenesosaan.

Käytön yleisyyteen perustuva komitatiiviosumien ja -lekseemien tarkastelu aineistossa tarkentaa siis kuvaa komitatiivisijan käytön kiteytyneisyydestä. Yleisimmän tuhannen osuman perusteella olisi täysin perusteltua pitää komitatiivin käyttöä kiteytyneenä (90 \% osumista kiteytyneitä). Yleisimmän kahdentuhannen osuman joukossa vielä kaksi kolmesta osumasta on kiteytyneitä, mutta kun tarkastellaan yleisintä puolikasta osumista (2 800 osumaa, jotka kattavat kaikki $\geq 3$ osuman lekseemit), enää vain puolta voi pitää kiteytyneinä. Lekseemien kohdalla kiteytyneisyys keskittyy vielä selvemmin: 10 yleisimmästä lekseemistä 9 on kiteytynyttä, 50 yleisimmästä kaksi kolmannesta ja 100 yleisimmästä puolet; yleisimmästä puolesta lekseemeistä $(n=1415)$ kiteytyneitä on vain reilu kymmenesosa. Kirjallisuuden esittämä -ine-sijan käytön kiteytyneisyys pätee siis vain frekventeimpiin lekseemeihin, jotka kattavat suhteessa suurimman määrän osumista. Se, mitä kiteytyneisyysväitteet eivät ota huomioon, on näiden ulkopuolelle jäävä

12 Kunkin luokan suhteellinen osuus kaikista osumista: A-C $21 \%$ ja D 37 \%; vrt. lekseemeistä: A 1 \%, $\mathrm{B} 7 \%, \mathrm{C} 18 \%$, D $74 \%)$. 
komitatiivilekseemien runsaslukuinen joukko, joista kullakin on tyypillisesti vain vähän osumia mutta jotka yhdessä muodostavat pääosan -ine-sijan käytöstä, niin -ine-sijaisista osumista kuin varsinkin lekseemeistä.

\subsection{Vakiintuneiden asiantilojen kielennys vs. muu käyttö}

Kuten edeltä nähdään, huomattava osa -ine-komitatiivin käytöstä HS20oo-korpuksessa on sellaista, jota ei voi pitää kiteytyneenä. Yksi selvä ero kiteytyneisiin käyttöihin on -inesijan ilmaisemassa merkityksessä. Suomen komitatiivisijahan ilmaisee prototyyppimerkityksensä lisäksi monia muita merkityksiä (ks. luku 1), mutta kiteytyneet komitatiivit keskittyvät vain muutamaan merkitykseen. Ensinnäkin kiteytynyt käyttö koskee sijan prototyyppimerkitystä, siis yhdessäolonilmauksia läheisten tai yleisemmin seura(laise)n kanssa (kuten perheineen, vaimoineen). Toiseksi kiteytynyttä käyttöä on meronyymisen osa-kokonaisuus-suhteen ilmaisuissa (kuten puu juurineen, peruna kuorineen). Kolmanneksi kiteytyneissä komitatiiveissa on yhteen liittymistä ilmaisevia muotoja (kuten kala höysteineen 'kala ja siihen liittyvät sen yhteydessä tarjottavat lisukkeet'), jotka usein saavat lausekontekstissaan myös 'mukaan lukien' -tulkinnan (kuten raportti liitteineen on 20 sivua = 'raportin pituus on 20 sivua, jos siihen liittyvät liitteet luetaan mukaan').

Sen sijaan komitatiivin käytön kiteytyneisyydestä annettujen esimerkkien joukossa ei ole yhtään sellaista, joka ilmaisisi esimerkiksi omistussuhdetta tai löyhää kokonaisuuden ja sen muodostavien osasten koostumissuhdetta. Korpuksessa näitä kuitenkin on runsaasti kuten omistamista ilmaiseva esimerkki 5 'tytön omistama(t) mukanaan kuljettama(t) kapsäkki (kapsäkit)' ja kokonaisuuden muodostavia osia erittelevä esimerkki 6 'kirjailija Heiner Müllerin näytelmästä Hamletkone välittyy naiskuva, joka koostuu (mm.) rinnoista, reisistä ja kohdu(i)sta'. Merkitysten eriytyminen viittaa siihen, että komitatiivin kiteytyneisyydessä ei oikeastaan ole kyse lekseemien kiteytyneisyydestä, siis komitatiivisijan kuulumisesta "melkeinpä vain joihinkin fraaseihin" (Vilkuna 200o) tai edes "tiettyihin sanoihin" (Eskola-Tommola 2000). Kyse on ennen kaikkea kielennettävien reaalimaailman asiantilojen vakiintuneisuudesta, niiden konventionaalisesta luonteesta.

(5) Seinäjoen tyttö tupsahti kapsäkkeineen suoraan lentokentältä studioon. (HS 3024040)

(6) Elisa Piispanen saa Ofeliaansa enemmän särmää, vaikka Müllerin naiskuva "rintoineen, reisineen ja kohtuineen" tuntuu vuoroin tympeältä, vuoroin huvittavalta. (HS 2566386)

On konventionaalista, että raporttien ohessa on selventäviä liitteitä tai pääruoalla höysteitä. Puu ja peruna puolestaan esiintyvät sekä juuret ja kuoret mukana että ilman niitä, jolloin konventionaalisuutta on täsmentää, kummasta on kyse. Mitä yhdessäolosuhteisiin tulee, yhteiskunnassa on paljon konventionaalisia ihmissuhteita, jotka usein perustuvat instituutioihin (kuten vaimoineen, perheineen ja esimerkiksi opettajineenoppilaineen, hoitajineen-potilaineen). Tämän lisäksi ihmisten on konventionaalista toimia ryhmissä, ja monille ryhmille on luonteenomaista hierarkinen rakenne, jossa on yhtäältä 
yksi keskeinen, johtavassa asemassa oleva henkilö (kuten tunnettu muusikko, kokenut tieteentekijä, keskeinen poliitikko) ja toisaalta tämän ympärillä toimivat (kuten yhtyeineen, tutkimusryhmineen, kannattajineen). Yhtä luonteenomaista on kielentää ryhmää ihmisiä siten, että yksi ryhmästä nostetaan kielennyksessä ilmauksen keskiöön (kuten Beck poliiseineen tai Tuomioja kollegoineen). Näissä yhteyksissä -ine-sijan käyttöä voi pitää suorastaan odotuksenmukaisena.

Sen sijaan reaalimaailmassa on varsin sattumanvaraista esimerkiksi se, mitä kukakin omistaa tai sattuu pitämään mukanaan (kuten korpuksessa aakkoston alkupäästä ajoneuvoineen, anomuskirjeineen, aseineen, autoineen, bassoineen, digitaalikameroineen ja eväskoreineen). Erityisen sattumanvaraisia ovat osista koostuvan kokonaisuuden merkityksessä käytetyt komitatiivilekseemit. Riippuu nimittäin pitkälle kulttuurista, kontekstista ja jopa yksittäisestä kielenkäyttäjästä, millaisista osista kukin kokonaisuus koostuu - tai nähdään koostuvan. Kulttuurista on esimerkiksi se, millaisista osista ateria koostuu (vrt. hämäläisen pitopöydän tarjottavia kuten suolakaloja, laatikoita ja paistia ranskalaiseen juhla-ateriaan esimerkissä 7), ja tilanteisena voi pitää vaikkapa tulevaisuuden eri osatekijöitä (vrt. esimerkit 8 ja 9). Pitkälti kielenkäyttäjän valintaa on puolestaan se, että haluaa määritellä Müllerin naiskuvan koostuvan juuri rinnoista, reisistä ja kohdu(i)sta eikä jostain muusta (ks. esimerkki 6).

(7) Tilauksesta saa myös 250 markan ranskalaistyylisen juhlamenun hanhenmaksoineen, täytettyine viiriäisineen, juustoineen ja omenapiiraineen. (HS 3520351)

(8) Tulevaisuus vanhuksineen, avohoitoineen ja kiireineen vaatii meitä kyllä nyt kehittämään nykyisten kokemusten pohjalta toimivan kotityöpalvelujärjestelmän. (HS 3046449)

(9) Huoli suomalaisen tv-kulttuurin säilymisestä ei ole turha. Digi-tulevaisuus edellyttää uusine kanavahankkeineen kaiken lisäksi valtavia voimavaroja. (HS 7948028)

Korpuksen perusteella -ine-komitatiivista hahmottuukin kaksi puolta. Toisaalta sillä on käyttöä, jota voidaan kutsua kiteytyneeksi. Konventionaalisten tilanteiden ja institutionaalisten suhteiden kielentäminen on väistämättä odotuksenmukaista ja sellaisena leksikaalisesti kiteytynyttä. Toisaalta komitatiivisijan avulla jäsennetään maailmaa ja siten luodaan uutta. Sitä käytetään määrittämään olioiden olemusta (kuten esimerkeissä 6-9) ja osoittamaan uusia yhteyksiä olioiden välillä (kuten esimerkissä 10, jossa komitatiivirakenteen avulla osoitetaan yhteys Concorde-lentojen ja joulun välillä). Tällöin on ilman muuta mahdotonta puhua leksikaalisesti keskittyneestä, odotuksenmukaisesta tai kiteytyneestä komitatiivin käytöstä, vaan kyse on vapaasta ja luovasta, siis produktiivisesta käytöstä. Niinpä -ine-komitatiivia voi pitää Baayenin (2009, luku 3.2.1) määritelmää seuraten sekä produktiivisena että epäproduktiivisena kategoriana. Nämä vain sijoittuvat eri kohtiin komitatiivin merkityskentässä: epäproduktiivinen käyttö merkityskentän ytimeen ja produktiivinen sen laidoille. 
(10) Matkailun edistämiskeskus markkinoi ulkomaille neljää jouluhanketta.

(...) Lapin valkea joulu Concorde-lentoineen on suomalaisista jouluista tunnetuin. (HS 11018230)

\section{Lopuksi}

Komitatiivin perusmerkitys, inhimillisten osapuolten epäsymmetrisen yhdessäolon ilmaiseminen, on selkeä mutta kielen ytimen kannalta ei kovin keskeinen merkitys. Suomessa -ine-komitatiivilla onkin sijoista pienin tekstifrekvenssi niin puhutussa kuin kirjoitetussa kielessä. Sijan käytöstä, erityisesti leksikaalisten esiintymien tasosta, kielenpuhujilla tuntuu olevan selvä intuitio: -ine-sijaa käytetään vain vähän ja silloinkin hyvin kiteytyneesti, vain joistain tietyistä lekseemeistä. Äärimmäisissä tulkinnoissa sitä on pidetty epäproduktiivisena sijana. Laaja sanomalehtikorpus kuitenkin osoittaa, että -ine-sijalla on sekä kiteytynyttä että vapaata, produktiivista käyttöä, kuten kielen muodoilla yleensäkin.

Tämän artikkelin luvussa 2 olen kartoittanut, mitä morfologinen produktiivisuus on ja mitä se sijamuodon yhteydessä tarkoittaa. -ine-komitatiivi on epäilyksettä sijamuoto, sillä typologisesti sijan kriteeri on, että muoto soveltuu kaikkiin substantiiveihin, ja kaikkia suomen substantiiveja voi taivuttaa -ine-sijassa. Tämän pidemmälle menevä taivutuksen produktiivisuuden tarkastelu keskittyy taivutustyyppeihin, mikä ei koske suomen komitatiivia. Ristiriitaan sijan selvän muodollisen produktiivisuuden ja kielenkäyttäjien intuition välillä löytyy ratkaisu odotuksenmukaisuudesta. Vaikka kaikkia substantiiveja voi taivuttaa -ine-sijassa, ei ole odotuksenmukaista tehdä niin. Tätä kahtiajakoa olen tarkastellut Bauerin (2001) avulla, joka erottaa produktiivisuudesta tarjouman ja toteuman ulottuvuudet.

Tarjouma kattaa komitatiivin muodolliset rajoitukset: -ine-sija on tarjolla kaikille substantiiveille sekä adjektiiveille, numeraaleille ja osalle pronomineja. Frekvenssit ovat puolestaan sijan toteumaa. Yksi puoli on tekstifrekvenssi, joka siis komitatiivilla on suomen sijoista pienin, myös HS20oo-korpuksessa. Toisesta puolesta, lekseemiesiintymien frekvensseistä - siitä, montako eri lekseemiä esiintyy kussakin sijassa jossain tietyssä tekstissä - ei suomen osalta näytä olevan tutkimustietoa (vrt. viron sijojen lekseemiesiintymistä Kaalep 2009). Produktiivisuuden arvioimisen kannalta tämä olisi kuitenkin mielenkiintoista erityisesti siksi, että produktiivisuuskirjallisuudessa on esitetty produktiivisuuden olevan yhteydessä nimenomaan lekseemiesiintymien frekvenssiin (varauksista ks. Bauer 2001, 48-49). Korpuksen komitatiivilekseemien määrän suhteuttaminen osumiin ja tämän vertaaminen essiiviin luvussa 3 osoittaa, ettei osumien pieni tekstifrekvenssi tarkoita pientä lekseemiesiintymien frekvenssiä eikä se välttämättä kerro muodon produktiivisuudesta.

Korpuksen analyysi luvussa 3 näyttää, että -ine-komitatiivilla on oletettua kiteytynyttä käyttöä mutta vielä enemmän vapaata ja siten produktiivista käyttöä. Kahtiajakoa havainnollistaa hyvin se, että kirjallisuudessa kiteytyneestä käytöstä mainitut esimerkit (siis kielenkäyttäjien intuitio) kattavat $10 \%$ korpuksen osumista mutta vain puoli prosenttia lekseemeistä. Niiden käyttö on siis omalta osaltaan kiteytynyttä, mutta koko komitatiivin 
käyttö ei ole kiteytynyt niihin. Jos aineistosta tarkastellaan konkreettisten esimerkkikomitatiivien sijaan kiteytyneeksi käytöksi hahmottuvia merkitystyyppejä, nämä kattavat $28 \%$ korpuksen osumista ja $10 \%$ lekseemeistä. Vain hyvin pieni osa tästä on varsinaista fraasimaista käyttöä (kuten niine hyvineen, omin nokkineen, sun muineen), ja pääasiassa kiteytyneessä käytössä on kyse siitä, että kielennettävät asiantilat ovat vakiintuneita. Läheisten ihmissuhteiden, meronymisten osa-kokonaisuus-suhteiden ja konventionaalisen yhteenliittymisen ilmauksissa komitatiivin käyttöä voi pitää jopa odotuksenmukaisena. Se, että sijaa käytetään odotuksenmukaisesti keskeisen sijafunktion mukaisissa tehtävissä, ei tee sijasta fraasiutunutta tai epäproduktiivista.

Komitatiivisijan toteuma ei ole produktiivisuuden asteeltaan tasainen, kuten ei varmasti minkään muunkaan sijan tai morfologisen prosessin toteuma. Toisaalta on se osa toteumaa, jossa pienellä määrällä komitatiivilekseemejä on paljon osumia, ja toisaalta se osa, jossa suurella määrällä komitatiivilekseemejä on hyvin vähän osumia. Tämä täyttää sekä produktiivisen että epäproduktiivisen kriteeristön, ainakin sen mukaan, miten Baayen (2009) kuvaa tekstifrekvenssin ja lekseemiesiintymien todistusvoimaa.

-ine-komitatiivin kannalta mielenkiintoista on se, miten produktiivinen ja epäproduktiivinen - siis kiteytynyt - käyttö näyttäisi jakaantuvan komitatiivin merkityskentässä: kiteytyneet -ine-käytöt ovat merkitykseltään suurelta osin komitatiivin merkityskentän ytimessä, kun taas produktiivinen käyttö on paljolti merkityskentän laitamilla. Tämä sopii suomen komitatiivin osalta käytyyn kieliopillistumiskeskusteluun (mm. Stolz ym.), jossa on esitetty, että -ine-komitatiivisija on muuttunut epäproduktiiviseksi ja väistynyt tai väistymässä kanssa-postposition tieltä, joka puolestaan olisi produktiivinen juuri komitatiivin prototyyppimerkityksessä. Se, mitä tämä keskustelu ei ota huomioon, on -ine-sijan monimuotoinen käyttö epäprototyyppisissä merkityksissä, jotka ovat vieraita tai mahdottomia kanssa-postpositiolle.

\section{Lähteet}

BAAYEN, HARAld 1993: Discussion. On frequency, transparency and productivity. Yearbook of morpho$\log y, 181-208$.

BAAYEN, R. HARALD 2009: Corpus linguistics in morphology: morphological productivity. AnKe LüDELING, Merja Kytö ja Tony McEnery (toim.): Handbook of Corpus Linguistics, luku 43, 819-919. Mouton de Gruyter, Berlin.

BaUer, LAUrie 2001: Morphological productivity. Cambridge UP, Cambridge.

Blake, BARry J. 2001: Case. Cambridge UP, Cambridge.

Bybee, Joan L. 2001: Phonology and Language Use. Cambridge UP, Cambridge.

Connexor $=$ Connexor dependency parser for Finnish. Suomen kielen morfosyntaktinen analysaattori. http://www.connexor.com.

Coseriu, Eugenio 1975: Sprachtheorie und allgemeine Sprachwissenschaft. 5 Studien. Wilhelm Fink Verlag, München.

Eskola, SARI - TOMmola, Hannu 2000: Komitatiivi ja kääntämisen lainalaisuudet. PÄIvi JAUHOLA, Outi Järvi ja Detlef Wilske (toim.): Erikoiskielet ja käännösteoria. Vakki-symposium XX, Vaasa 11.-13.2.2000. Vaasan yliopiston käännösteorian ja ammattikielten tutkijaryhmän julkaisut 26, 96-109. Vaasan yliopisto, Vaasa. 
Fernández-Domínguez, Jesús 2010: Productivity vs. lexicalization: Frequency-based hypothesis on word-formation. Poznań Studies in Contemporary Linguistics 46 (2), 193-219.

Grünthal, Rino 2000: Typological charasteristics of the Finnic languages: a reappraisal. Johanna LAakso (toim.): Facing Finnic. Some Challenges to Historical and Contact Linguistics. Castrenianumin toimitteita 59, 31-63. Suomalais-Ugrilainen Seura - Helsingin yliopisto, Helsinki.

2003: Finnic Adpositions and Cases in Change. Suomalais-Ugrilaisen Seuran toimituksia 244. Suomalais-Ugrilainen Seura, Helsinki.

Hakulinen, Auli - Vilkuna, Maria - Korhonen, Rittta - Koivisto, Vesa - Heinonen, Tarja RiItTA - AlHo, Irja (toim.) 2004: Iso suomen kielioppi. Suomalaisen Kirjallisuuden Seuran toimituksia 950. Suomalaisen Kirjallisuuden Seura, Helsinki.

Haspelmath, Martin 2002: Understanding morphology. Arnold, London.

2009: Terminology of case. Andrej Malchukov ja Andrew Spencer (toim.): The Oxford Handbook of Case, luku 33, 505-517. Oxford UP, Oxford.

Hynönen, Emmi 2013: Essiivisijaisten tilanilmausten leksikaalistumisjatkumo. Virittäjä 117 (4), 551579.

2016: Suomen essiivi. Turun yliopiston Kieli- ja käännöstieteiden laitos. Sähköinen aineisto URL: http://urn.fi/URN:ISBN:978-951-29-6563-2.

HäKKINEN, KAISA 1994: Agricolasta nykykieleen: suomen kirjakielen historia. WSOY, Porvoo.

IgGeSEN, Oliver A. 2009: Asymmetry in case marking: nominal vs. pronominal systems. A. MALCHUKov ja A. SPenCER (toim.): The Oxford Handbook of Case, luku 16, 246-257. Oxford UP, Oxford. 2011: Asymmetrical Case-Marking. Matthew S. Dryer ja Martin Haspelmath (toim.): The World Atlas of Language Structures Online, luku 50. Max Planck Digital Library, Munich. Verkkojulkaisu, URL: http://wals.info/chapter/5o (luettu 7.4.2016).

IкоLA, Osmo 1999: Havaintoja komitatiivin käytöstä suomen murteissa ja yleiskielessä. Sananjalka 41, 59-80.

KAALeP, Heiki-JaAn 2009: Kuidas kirjeldada ainsuse lühikest sisseütlevat kasutamisandmetega kooskõlas? Keel ja Kirjandus 52 (6), 411-425.

Korpela, JukKa K. 2004-2015: Nykyajan kielenopas. Verkkojulkaisu, URL: https://www.cs.tut. fi/ jkorpela/kielenopas/index.html (luettu 21.4.2016).

NAU, Nicole 1995: Möglichkeiten und Mechanismen kontaktbewegten Sprachwandels unter besonderer Berücksichtigung des Finnischen. Edition Linguistik 08. Lincom Europa, München - Newcastle.

Nikolaev, AleXANDre 2011: Suomen nominien taivutusjärjestelmän produktivisuudesta: korpuslingvistisiä ja kokeellisia tutkimuksia. Väitöskirja. Itä-Suomen yliopisto.

Pajunen, ANNELI 2003: HS2000-korpus. Helsingin Sanomat 2000-2001. Tietokanta, morfosyntaktinen analysointi: FDG-jäsennin, Connexor; haku: ContextMill; n. 31 milj. sanamuotoa.

2006: Verbisanasto uudistuu. Puhe ja kieli 26 (4), 205-219.

2010: Sanojen synteettisyys suomen kielessä. Virittäjä 114 (4), 481-50o.

Penttilä, Aarne 1957: Suomen kielioppi. WSOY, Porvoo - Helsinki.

PlaG, INGO 1999: Morphological Productivity: Structural Constraints in English Derivation. Mouton de Gruyter, Berlin.

Sirola-Belliard, Maija 2011: Is there a future for the Finnish comitative? Arguments against the putative synonymy of the comitative case -ine and the postposition kanssa. SEPPo Kittilä, Katja VÄsti ja Jussi Ylikoski (toim.): Case, animacy and semantic roles. Typological Studies in Language 99, 135-153. John Benjamins, Amsterdam.

__ 2013: Kurkistus komitatiivin sielunelämään. Kielikuvia 1/2013, 4-21.

2016: Suomen komitatiivi. -ine ja kanssa. Acta Universitatis Tamperensis 2219. Tampere University Press, Tampere. Sähköisenä Acta Electronica Universitatis Tamperensis 1719, URL: http:// urn.fi/URN:ISBN:978-952-03-0246-7.

Stolz, Thomas - Stroh, Cornelia - Urdze, Aina 2005: Comitatives and instrumentals. Martin Haspelmath, Matthew S. Dryer, David Gil ja Bernard Comrie (toim.): The World Atlas of Language Structures, luku 52, 214-217. Oxford UP, Oxford.

2006: On comitatives and related categories: A typological study with special focus on the languages 
of Europe. Mouton de Gruyter, Berlin - New York.

Stolz, Thomas - Stroh, Cornelia - Urdze, Aina 2009: Varieties of comitative. Andrej Malchukov ja ANDrew SPENCER (toim.): The Oxford handbook of case, luku 41, 601-608. Oxford UP, Oxford.

Taajuussanasto 9996 = Suomen sanomalehtikielestä vuonna 2004 koottu taajuussanasto, joka sisältää 9996 yleisintä lemmaa laskettuna 43999826 sanan korpuksesta. Kielipankki, CSC - Tieteen tietotekniikan keskus. Saatavissa URL: https://korp.csc.fi/suomen-sanomalehtikielen-taajuussanasto-B9996.txt (luettu 20.4.2016).

VILKUNA, MARIA 2000: Suomen lauseopin perusteet. Kotimaisten kielten tutkimuskeskuksen julkaisuja 90. Edita, Helsinki.

Virtanen, PATriK 2000-2003: ContextMill. The easy-to-use concordancer. Aurit Software.

Wikipedia, vapaa tietosanakirja: Komitatiivi. Verkkodokumentti, URL: http://fi.wikipedia.org/wiki/ Komitatiivi (luettu 6.4.2016).

\section{Maija Sirola-Belliard: The Finnish comitative -ine - a fixed or a productive case ending?}

The comitative is a morphological form, such as an adposition, a case affix or a serial construction, which prototypically expresses the accompaniment of human participants. The main forms in Finnish are the comitative case -ine, accompanied by an obligatory possessive suffix (e.g. lapsineen child-com-Poss.3 'with one's child/ren') and several postpositions among which kanssa is the most common (e.g. lapsen kanssa child-GEN with 'with a child'). In spite of its larger functional domain, -ine is used considerably less frequently than kanssa which is concentrated mainly on the prototypical function.

The low frequency of -ine might be one reason for the assumptions made in the literature used for this study that the usage of the Finnish comitative case is only seen in some fossilised expressions. The case has been called fixed and unproductive. However, no actual data has been shown to justify these claims. This paper examines the actual usage of the case ending -ine based on a 31 million-word contemporary newspaper corpus and shows that its usage is not as fixed or unproductive as proposed.

Discussing the productivity of a case affix belongs to the domain of morphological productivity. Its most straightforward definition is "the ability of a linguistic pattern to apply to new items". As for a more precise definition, there is no general consensus, and how to apply it to inflection is not clear either. This paper uses the definition given by Bauer (2001). He divides morphological productivity into two distinct senses: availability refers to the potential for a morphological process to be applied to new words, and profitability examines how largely the process really is exploited in language use. The latter is connected to two dimensions: the token (or textual) frequency is concerned with the number of times a pattern occurs within a text and the type (or lexical) frequency refers to the number of different items to which the pattern has been applied in a text. Although there are some restrictions concerning the availability of -ine (it is not available for e.g. personal pronouns), the case is clearly productive in the sense of profitability in the corpus.

One approach to the putative non-productivity of the comitative case is to consider the accumulation of comitative tokens on a lexeme-by-lexeme basis in the corpus. It shows that there are only a few common lexemes and plenty of those that occur in the corpus only once or a couple of times. Even though this suggests that certain usages are fixed, it is not an indication of non-productivity of the case, but rather the normal behaviour of the lexicon. By comparison, the corpus shows, for example, that the usage of the Finnish essive ending - $n A$ is even more concentrated on a small set of lexemes than the usage of the comitative case. Nevertheless, no one considers the Finnish essive to be unproductive. 
Another approach is to take, as a starting point, the specific phrases that have been noted in the literature as examples of fixed comitative expressions. These cover $10 \%$ of the comitative tokens, but only $0.5 \%$ of the comitative lexemes in the corpus. Based on the given examples, five categories of meanings considered to be the fixed usage of the case can be formulated: 1) close human relationship (e.g. vaimoineen 'with one's wife'), 2) more general human accompaniment (e.g. seurueineen 'with one's company'), 3) inherent part-whole relationships (e.g. puu juurineen 'tree with its roots') and inclusion of interrelated participants (e.g. pöytäkirja liitteineen 'minutes with its appendix/es'), 4) intensifying usage (e.g. lapsineen päivineen 'with one's child/ren and all'), and 5) true fossilised expressions (e.g. omine nokkineen own-сом beak-сом 'by oneself, without any help').

All the comitative forms in the corpus that can be interpreted as belonging to these categories cover $28 \%$ of the comitative tokens and $10 \%$ of the comitative lexemes. Among the words most commonly inflected in the comitative, the coverage is quite comprehensive ( $90 \%$ of the most common 1,000 tokens and the most common 10 lexemes), but the lexemes that are rarely inflected in the comitative mostly express other meanings (among the lexemes in the corpus which occur one to three times with the comitative case, only $8 \%$ of the tokens and $7 \%$ of the lexemes belong to the fixed categories).

The fixed usage is linked with canonical meanings expressed by the comitative case: the accompaniment of the human beings, the inherent part-whole relationships and the inclusion of interrelated participants. These reflect conventional situations found in the real world. Among the proposed fixed usages, there are none that would express a random situation, such as possession (e.g. tyttö kapsäkkeineen 'girl with her suitcase(s)') or components which a non-inherent unit comprises (e.g. tulevaisuus vanhuksineen, avohoitoineen ja kiireineen 'future comprises the elderly, the treatment of outpatients and being busy'), although these are commonly expressed by -ine in the corpus. Indeed, the random situations are those that -ine expresses very productively. In a significant part of the corpus, -ine is used to portray the world by describing the substance of entities and showing connections between different entities.

Consequently, -ine fulfils the criteria for both productive and unproductive forms, but these are situated in different parts of the functional domain of the case. The fixed usage that is characterised by a few very often used lexemes - and thus can be considered unproductive - is concentrated in the centre of the functional domain. However, the main part of the usage of -ine comprises comitative lexemes that only occur once or a few times in the corpus, and thus can be considered to be part of the productive usage of the case. These usually express meanings located at the border of the functional domain. Hence, they are out of the scope of the postposition kanssa, which concentrates on the prototypical meaning of the comitative. This strongly suggests that kanssa can hardly takeover the comitative case in a grammaticalisation process as it has been assumed.

Maija Sirola-Belliard maija.belliard@uta.fi 